\title{
The Morphodynamics of Wulan Delta and Its Impacts on the Coastal Community in Wedung Subdistrict, Demak Regency, Indonesia
}

\author{
Muh Aris Marfai*, Desy Wahyuning Tyas, Idham Nugraha, \\ Ayu Fitriatul'Ulya, Widiana Riasasi \\ Faculty of Geography, Universitas Gadjah Mada, Yogyakarta, Indonesia \\ Email: *arismarfai@yahoo.com
}

Received 27 November 2015; accepted 8 January 2016; accepted 11 January 2016

Copyright (C) 2016 by authors and Scientific Research Publishing Inc.

This work is licensed under the Creative Commons Attribution International License (CC BY).

http://creativecommons.org/licenses/by/4.0/

c) (i) Open Access

\begin{abstract}
Wulan Delta in Central Java has been experiencd coastal morphodynamics due to interface between Wulan River's sedimentation and Java sea's oceanographic process. This paper aims to analyze Wulan Delta's morphodynamics as well as its impacts on the socio-economic condition of the community. The morphodynamics is interpreted visually and digitally using a maximum livelihood analysis of multi-scale and multi-temporal images. The socio-economic impact is defined by field observations and in-depth interviews to the community and stakeholders. Analysis during the period of 1931-2010 showed that Wulan Delta had been changed morphologically from straight with small arc-like (arcuate) to bird-foot (digitate) with a plausible change into rounded (lobate) in the future, which represented dominant sedimentation by oceanographic rather than fluvial processes. Land expansion in Wulan Delta led to landuse change in Wedung, i.e. expansion of settlement area to 167 ha and fish pond area to 1014 ha in 2000-2010. Most settlements in the area, which are built linearly to river levees, own a high vulnerability to both river flood and tidal inundation. Therefore, dissemination about knowledge of the disaster and coastal zone management, as a means of increasing awareness, becomes necessary in integrating the coastal management in Wulan Delta together with improvement in infrastructure and proper regional development. The proper development strategy for the coastal village is aggressive maintenance strategy, including public infrastructure revitalization, quality improvement for human resources, and silvofishery system. Law enforcement on coastal zoning regulations is necessary to achieve an integrated and sustainable coastal zone management.
\end{abstract}

${ }^{*}$ Corresponding author.

How to cite this paper: Marfai, M.A., Tyas, D.W., Nugraha, I., Fitriatul'Ulya, A. and Riasasi, W. (2016) The Morphodynamics of Wulan Delta and Its Impacts on the Coastal Community in Wedung Subdistrict, Demak Regency, Indonesia. Journal of Environmental Protection, 7, 60-71. http://dx.doi.org/10.4236/jep.2016.71006 


\section{Keywords}

\section{Coastal, Morphodynamics, Wulan Delta, Demak Regency}

\section{Introduction}

Indonesia was an archipelago with $99.093 \mathrm{~km}$ shoreline length [1]. A shoreline is a highly dynamic land-sea interface due to the influence of tides, waves, sedimentation processes, and human activities. Meanwhile, a shore is part of a coastal area located between the highest and the lowest tides [2], whose seaward border is a wave breaker zone and landward border is the outer boundary of coastal alluvial plain [3]. Therefore, it displays a highly dynamic area with variously complex land uses [4] [5]. Coastal area is uniquely dynamic because it is an intersection of hydrosphere, lithosphere, and biosphere components [6]. However, being an interface experiencing the effects of both land- and sea-induced processes, a shore has the most complex processes than the other parts of a coastal area [7] [8]. Shore dynamics is affected by land- and sea-induced as well as atmospheric processes and human activities. The land-induced, for instance, fluvial processes involving water and sediment transports from hinterland to the ocean plausibly affect coastal geomorphology, i.e. morphology and sediment constituent [5]. Meanwhile, processes occurring from the sea are induced by the dynamics of waves, surges, oceanic sirculations, currents, tides [9]-[11], and sea level rise [12]. Sea waves are dominantly formed by wind movement above the sea surface [13]. Beside wind energy, wave character is influenced by topography of seabed [14]. The wave induces current and sediment transport, and may occur in multiple pathways, that affect morphodynamics [15]. The whole processes occurring in a coastal area collaborate in forming a distinctive geomorphological condition in accordance with the characteristics of each process. The coastal evolution is directed towards a relatively static equilibrium [16]. Coastal area adjusts its morphology in a way that reduces the energy working on it. In conclusion, coastal area constantly experiences an adjustment process to a point of natural equilibrium due to the impact of sea and land activities, i.e. either natural or man-induced [17].

Delta, as one of several highly dynamic coastal ecosystems, is a landform where deposition process from the river creates a flat coastal area and, therefore, causes irregular shoreline progradation [18] [19]. River delivers water and sediment from watershed to estuary [20]. The sediment is redistributed by marine processes [21] that delta can be defined as fluvio-marine landform. The existence of delta at the mouth of a river is influenced by sediment inputs, fluvial processes, tectonic stability, waves, currents, and tides [22]. Most deltas in Java are formed on the northern coastal area because both of its wave and current energy are relatively low. One of which is Wulan Delta.

Wulan Delta is located in the northern part of Demak (Figure 1). This delta is formed by the sedimentation processes of Wulan or Serang River whose recharge area is located on the volcanic cone of Muria, Rembang Hills, and Kendeng Hills. Muria is an old volcanic landform composing of weathered rock. Meanwhile, Rembang and Kendeng Hills are karst landforms and partly denudated hills. The old, weathered rock and soil are highly susceptible to erosion. At the same time, erosion in this area is exacerbated by the upstream land use dominance of agricultural land and built-up area, resulting in a large amount of material being transported by Wulan River. This material is also easily deposited at the mouth of Wulan River due to low wave and current energy. Consequently, the mouth of the river progrades continuously and, forms Wulan Delta whose extent gets wider every year.

The morphodynamic Wulan Delta causes land use conversion from mangroves to fishponds, used as a local livelihood source. Furthermore, the continuously changing extent of Wulan Delta would likely trigger land ownership conflicts. Therefore, an analysis of the morphodynamics of Wulan Delta as well as its physical and social impacts becomes necessary. This paper aims to analyze the morphodynamics of Wulan Delta using multi-temporal remote sensing images and to analyze its impacts on the socio-economic condition of the local community. The results provide a reference on integrated coastal zone management of Wulan Delta, including management of the upper watershed that provides sediment in Wulan Delta.

\section{Method}

This research was conducted in the coastal area of Wulan Delta which is located administratively in two villages, 

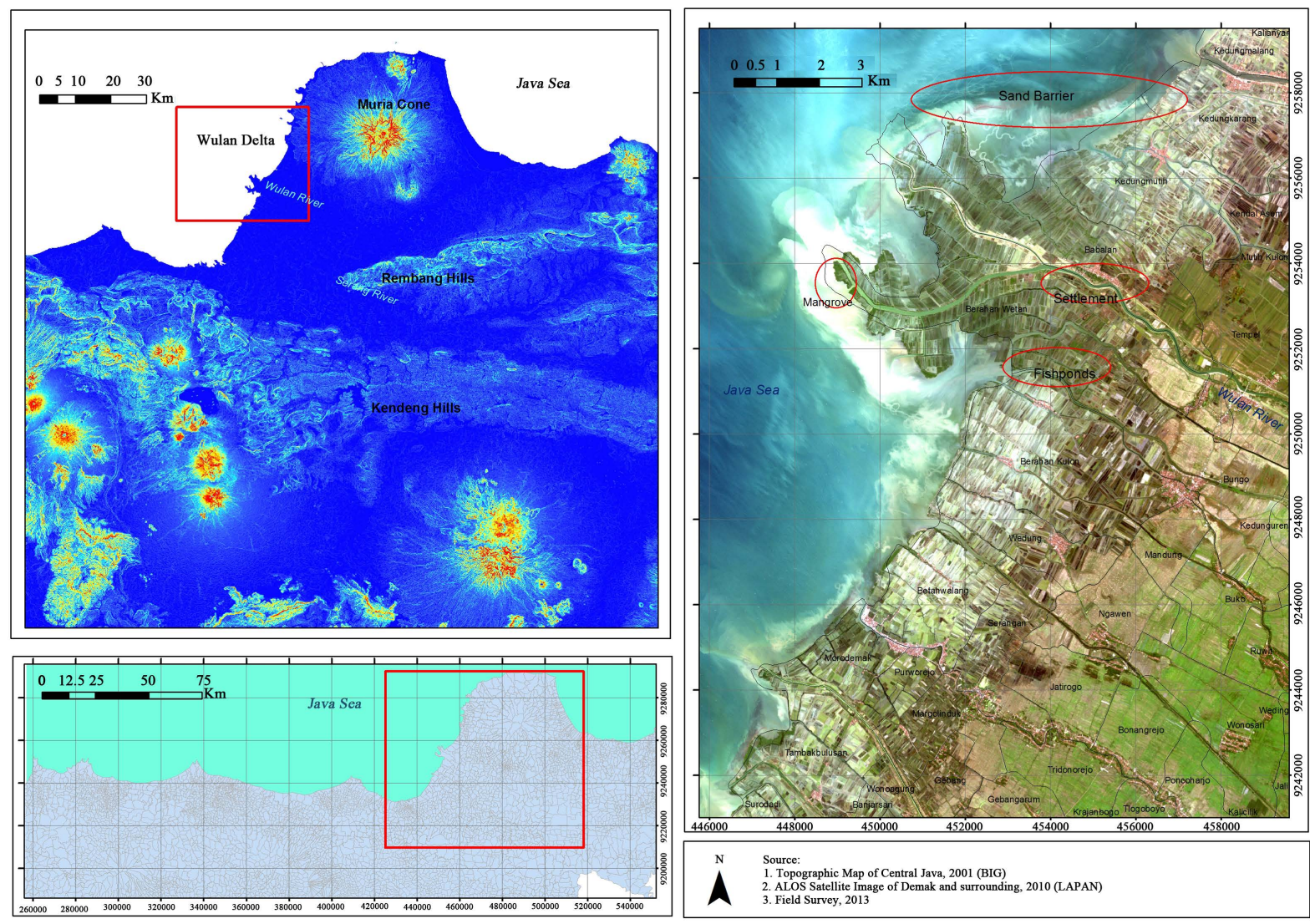

Figure 1. Physical condition of Wulan Delta, Demak, Central Java.

i.e. BerahanWetan and Babalan, Wedung Sub-district, Demak Regency, Indonesia. The research methods include shoreline extractions on Wulan Delta and analyses of oceanographic characteristics, land use changes, and social conditions affected by shoreline and land use change. Shoreline extraction was performed using visual and digital interpretation of geospatial data. Visual interpretation used the 1931 topographic map $(1: 50,000)$, the 2001 Indonesian Topographic Map (1:25,000) from the 1999 database, and an Alos satellite image in 2010. Meanwhile, digital interpretation used maximum livelihood analysis on the 1972 Landsat MSS image and the 2002 Landsat 7 image. Maximum livelihood analysis classifies pixel values based on Bayes' rules. Separability analysis is required in determining the pixel class in order to identify the separability of the classified objects. This analysis used Jeffries-matuista and Transformed Divergence methods with "Compute ROI Separability" option in ENVI 4.5 software. The separability value has a range of 0 to 2, and indicates a good separability whenever the value approaches 2 classified the transformed divergence value into five (5) classes, i.e. $<1600$ (not separated); 1601 - 1699 (badly separated); 1700 - 1899 (separated); 1900 - 1999 (well separated); and 2 (perfectly separated) [23]. Figure 2 shows the results of separability classification using a maximum likelihood method.

The oceanographic characteristics were analyzed using Sverdrup Munk Bretschneider (SMB) method on the wind data obtained from the Agency for Meteorology, Climatology and Geophysics (BMKG) Maritime Semarang. SMB method considers the length of the wind path (fetch), which affects both height and speed of wind-induced waves and currents. Wind data was firstly converted into wind speed above the sea surface by considering the different wind stress factors between the land and the sea.

Land use analysis included a visual interpretation on satellite images and maps in 2000 and 2010. Furthermore, a correction was also conducted based on field observations and in-depth interviews on land use change. Physical and social conditions were identified from surveys on institution, literature studies, and in-depth interviews to local community. Primary data acquisition was conducted on May 27-29 and June 11-13, 2013.

Coastal management recommendation was determined using analysis of Strengths, Weaknesses, Opportuni- 

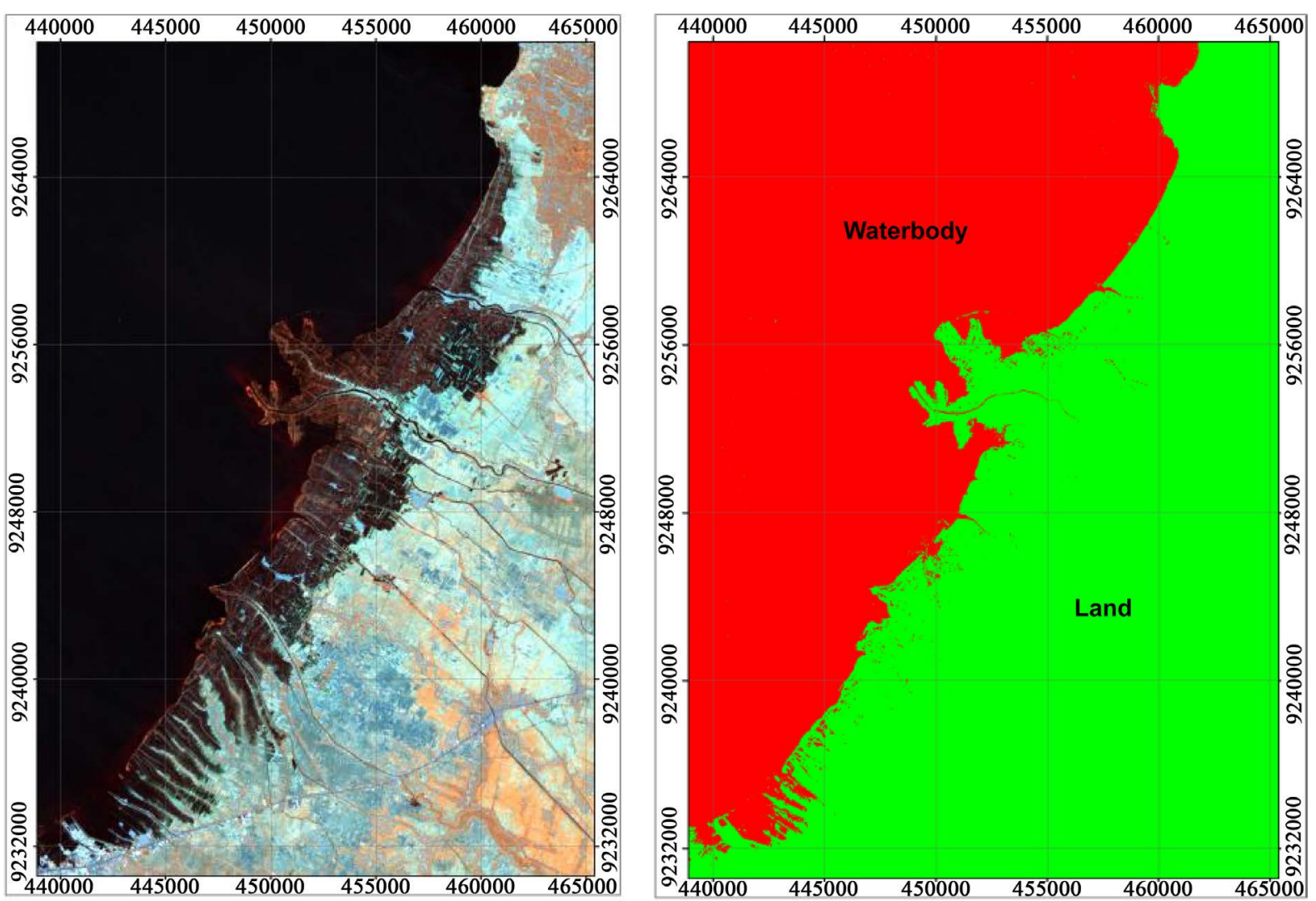

Figure 2. The 2002 Landsat Image ETM + 457 Composites (left) and the Result of Maximum Likelihood Classification (right).

ties, and Threats (SWOT) which identifies the influencing factors of an object based on internal (strengths and weaknesses) and external (opportunities and threats) factors. Each factor is inventoried and presented in the formulation matrix for management strategy.

\section{Result and Discussion}

\subsection{Oceanic Condition on Wulan Delta}

Based on the bathymetric map of Java Sea, the mouth of Wulan River and its surrounding area have a depth of 0 - $10 \mathrm{~m}$. The shallow and flat coastal area of Wulan Delta causes waves to break and, then, results in relatively low wave energy. Low wave energy is not able to transport the sediment emptied out by Wulan River. As a result, the sediment is deposited around the mouth of the river.

According to the daily maximum wind data in 2002-2012, obtained from the Maritime Meteorology, Climatology and Geophysic Agency (BMKG Maritime) of Semarang, the wind changes direction in every season. Wulan Delta is influenced by a monsoonal climate that divides a year into four seasons, i.e. West, Transition I, East, and Transition II. During the West season (December-February), wind dominantly blows from the west (32.16\%) in a speed of 0 - 10 knots (51.31\%). Meanwhile, during the Transition I season (March-May), wind blows from various directions, i.e. from the east (31.36\%), north (19.39\%), southeast (12.76\%), and northwest (18.50\%). Furthermore, this wind blows dominantly with a speed of 0 - 10 knots $(77.80 \%)$, while a more than 27 -knot wind speed only occurs for $0.1 \%$. During the East season (June-August), wind dominantly blows from the east (62.55\%) with an average wind speed of 9.62 knots. Meanwhile, during the Transition II season (September-November), wind blows dominantly from the east (37.30\%) with a dominant speed of 0 - 10 knots (50.0\%) and 10 - 15 knots (41.30\%).

A wind is considered as a causal factor in the development of Wulan Delta whenever it blows inshore and has a capability of inducing sea waves and currents. Wind speed data shows that such influencing wind blows from 
the west (12.35\%), north (19.39\%), and northwest (20.65\%). Therefore, an optimum development of Wulan Delta occurs during the seasons of West, Transition I, and Transition II.

Based on sea waves analysis using the Sverdrup Munk Bretschneider (SMB) method on the 2002-2012 wind data, more sea waves are induced by west wind (55\%) during the west season, however, their height is relatively low, i.e. 1.5 - $3 \mathrm{~m}$. Meanwhile, both north and northwest wind induced waves with a height of higher than $2 \mathrm{~m}$ up to $4 \mathrm{~m}$. Primary measurement on June 11, 2013 up to $11.24 \mathrm{a} . \mathrm{m}$. (High tide) shows that the wave around Wulan Delta was $4.77 \mathrm{~m}$ in height and $19.24 \mathrm{~m}$ in length. The wave experienced refraction due to a change in depth, causing a wave break on the height of $3.55 \mathrm{~m}$. At the same time, measurement at 03:26 p.m. (low tide) shows that the wave had a height of $2.13 \mathrm{~m}$ and a length of 22.53, and broke at a height of $1.92 \mathrm{~m}$.

Seawater around Wulan Delta has a tidal range of less than $2 \mathrm{~m}$; thus, it is categorized as microtidal [8]. Based on the Formzahl number of 2.43, this area has a mixed tidal with prevailing diurnal and, therefore, experiences one flood and one ebb, sometimes two floods and two ebbs, each day. Regarding the condition of waves and seawater tides, materials from Wulan River are not transported far from the mouth of the river but deposited at the shallow seawater resulting in coastal progradation.

\subsection{The Morphodynamics of Wulan Delta}

Morphodynamics is a landform geomorphological change due to exogenous factors. Delta is a coastal landform influenced by exogenous factors such as fluvial and marine processes, for instance, Wulan Delta experiences both fluvial processes, originated from Wulan River, and marine processes, induced by the wave and current energy of Java Sea. Wulan Delta has a bird-foot shape (digitate) with a curved shoreline. Its composing material is originated from the upper part of Serang River, which is Muria Volcano in the north and Rembang and Kendeng Hills in the south. Based on Whitten et al., Serang Watershed has an area of $3860 \mathrm{~km}^{2}$ with an average annual rainfall of $2450 \mathrm{~mm}$ and a surface discharge of $29 \mathrm{~m}^{3} \cdot \mathrm{s}^{-1}$ [8]. Meanwhile, Bendung Klambu recorded that Wulan River had a discharge of $675.79 \mathrm{~m}^{3} \cdot \mathrm{s}^{-1}$ in 1951-2006 [24]. Having a large catchment area with an upper part composed of an old volcanic landform, karst hills, and denudated hills, material transported by Wulan River is a very fine sediment. The composing material of delta is mud with hydromorph alluvial soils [8] that have a grayish brown color with a texture of 2:1 clay (montmorillonite) and, therefore, have a blocky-solid structure with low permeability.

Landform units in Wulan Delta are composed of mud flats on the delta front and tidal flats on the delta plain. Tidal flat is a marine landform influenced by seawater tides and composed of mud. Mud comes from the overflow during flood events in Wulan River and forms wider tidal flats. Based on the information obtained from local community, there has not been a major flood in the last 10 years, causing less mud supply. Consequently, some parts of Wulan Delta have been experiencing coastal erosion. The nowadays flood occurs in a small overflow which only inundates the nearby floodplains and back swamps of Wulan River. Figure 3 shows the shoreline morphodynamics of Wulan Delta within a period of 1931-2010.

Wulan Delta was initially formed due to the scenario to direct the sediment flow of Serang River to the southern shore of Jepara through Wulan Canal in 1892 [17]. Wulan Canal was built for agricultural irrigation purposes in Wedung Sub-district, Demak. Prior to 1892, the coastal area had a straight shore shape or, called as, a strand plain. The large amount of sediment transported by Wulan River made Wulan Delta continue to develop. In 1931, Wulan Delta is arcuate type. It is generally straight shoreline with some parts of the shoreline protruded the mouth of Wulan River, looks arc-like. Furthermore, there had been a significant sediment supply within a period of 41 years (1931-1972), which changed the shape of Wulan Delta into tooth-like with less curved shoreline (cuspate) and then bird-foot. This supply is deemed larger than the 39-year sediment supply during the earlier development of Wulan Delta. Until the year of 1972, Wulan River only owned one main, northwestward river channel nearly perpendicular to the shoreline orientation.

The 2000 satellite image indicates that the left side of Wulan Delta has been developing westward due to the westward tributary formation of Wulan River. This tributary has been developing together with a larger river channel. In addition, Wulan River has several small tributaries formed both naturally and artificially for irrigation purposes. The nowadays shape of Wulan Delta is bird-foot with a curved shoreline. The large amount of sediment supply as well as the constructive oceanographic characteristic of Java Sea becomes the key causes of Wulan Delta development. Sunarto stated that Wulan Delta will continue to develop northwestward until a point where the main channel of Wulan River reaches the ocean trench [8]. The ocean trench is a north-south lineament located $4 \mathrm{~km}$ from the mouth of the main river channel [25]. 

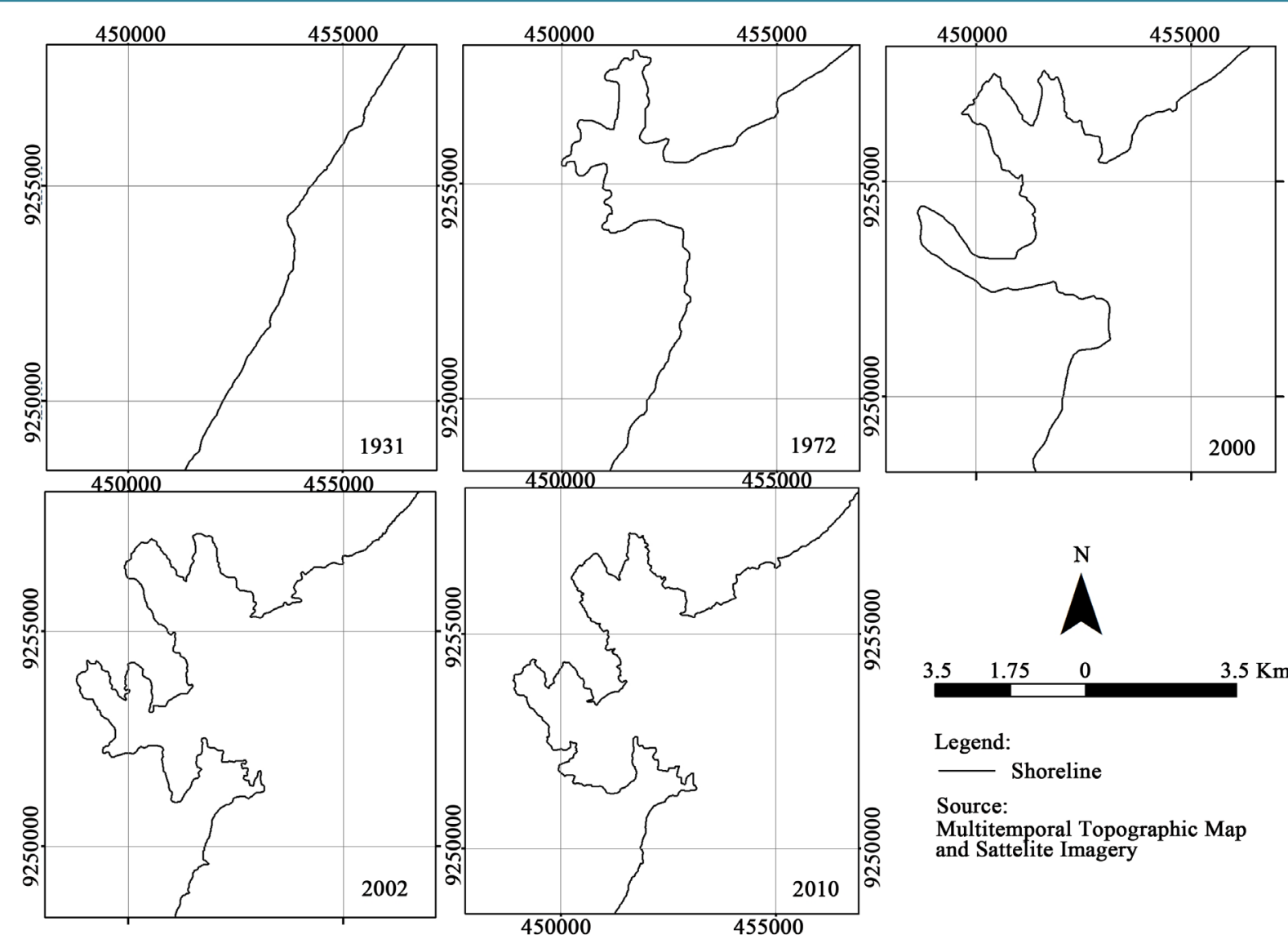

Figure 3. The Development of Wulan Delta within a period of 1931-2010 (Source: modified from Sunarto, 2004).

Despite the progradation tendency of Wulan Delta, some parts of this delta experience coastal erosion (see the red-circled area in Figure 4), which is caused by the wave and sea current pattern change resulted from the shoreline change. Part of land that protrudes into the sea becomes wider so that they affect the sediment-loaded current pattern along the shore. However, sedimentation along the shore does not occur in locations that are obstructed by the protruded delta.

The left map in Figure 4 shows that Wulan Delta, acting as a barrier, obstructs the sedimentation processes of the southwest-east current on the eastern part of the delta. Within a period of 1931-1972, coastal erosion in Wulan Delta occurred in the northern part resulting in a shoreline retreat for $200-600 \mathrm{~m}$ or about $4-16 \mathrm{~m} /$ year. On the contrary, the middle map in Figure 4 shows that during a period of 1972-2000, the southwestern part of the apex was eroded with a range of $200-250 \mathrm{~m}$ or $7-9 \mathrm{~m} /$ year due to the inability of the northeast current in depositing materials on the south side of the delta. At the same time, the mud supply from Wulan River and the surrounding small river was decreasing. The right map in Figure 4 shows that coastal erosion in 2000-2010 occurred due to a decrease in sediment supply resulting in a shoreline retreat in Wulan Delta with a rate of 66 $\mathrm{m} /$ year (see circled area in the map). Furthermore, this coastal erosion is influenced by the absence of sediment supply and, at the same time, the more intensive marine activities due to climate change-induced wave and current energy.

\subsection{Sand Barrier}

The sea waves around the Wulan Delta transport sediments from the river and deposit them around the delta forming sand barrier (Figure 5(a)). Sand barrier consists of black colored sand deposited with mollusk shell fractions (Figure 5(b)) known as chenier [8]. The materials coming from the upper part of Serang Watershed are transported into Java Sea and, then, deposited by sea currents and waves forming a long beach at some parts of the delta front. Most parts of sand barrier are periodically inundated by seawater during high tides, and the 

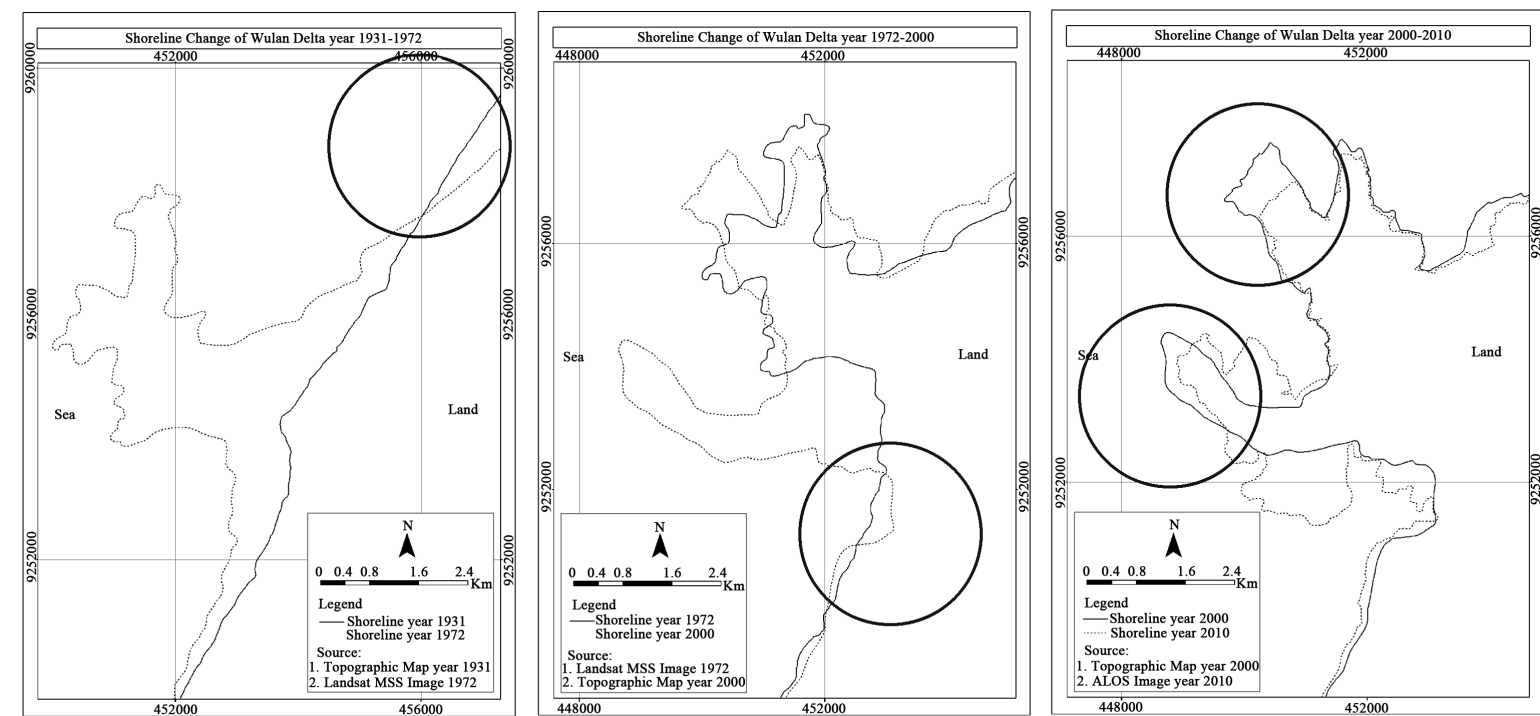

Figure 4. The shoreline changes of Wulan Delta in 1931-2010.

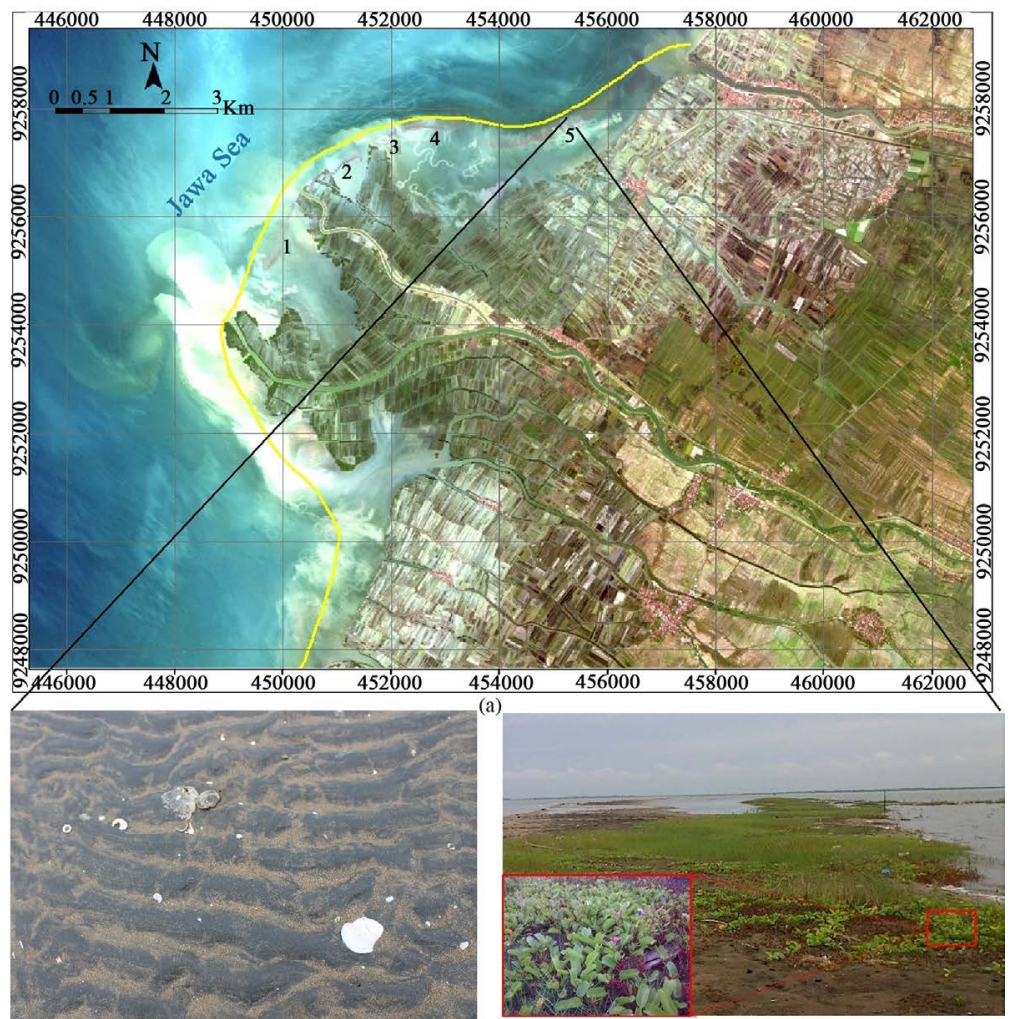

(c)

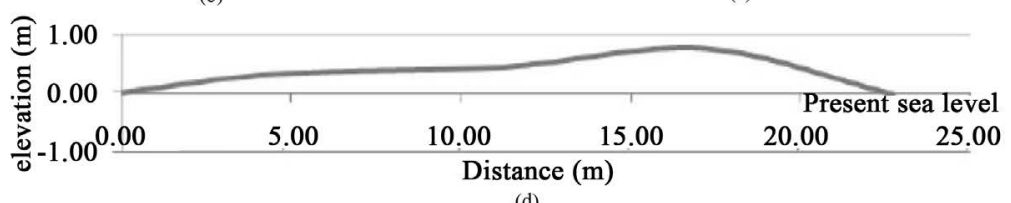

(d)

Figure 5. (a) Sand barrier formed in front of Wulan Delta, indicating the dominance of current and sea wave in the sedimentation process; (b) the composing materials: sand and mollusk shell fraction; (c) beach morning glory found in some areas on the sand barrier; (d) the cross section of sand barrier no. 5 during low tide. 
opposite applies during low tides. In addition, beach moring glory plant (Ipomoea pes-caprae) or locally known as tapakkambing (Figure 5(c)) is found at some points in the delta indicating non-inundated area even during the highest tides. The measurement of sand barrier on June 11, 2013 at flood tide (5:19 p.m.) shows that sand barrier no. 5 (Figure 5(a)) has a width of $22.7 \mathrm{~m}$ and a length of $2.4 \mathrm{~km}$. This sand barrier is the longest deposition compared to other depositions that have a length of $300 \mathrm{~m}$ to $1.4 \mathrm{~km}$ formed in front of Wulan Delta.

The formation of sand barrier indicates that sea currents and waves proceed dominantly among the other influencing processes in a delta development [19]. The existence of sand barrier in front of Wulan Delta represents that the sedimentation in this delta is no longer controlled by fluvial processes but current-and wave-induced processes. Such condition leads to a shape change, i.e. from bird-foot (digitate) into more rounded (lobate). Sand barrier prevents fluvial sediments from being transported offshore so that they are deposited in shallow seawaters located between delta and sand barrier. In the future, this seawater will be loaded by terrestrial materials and form a rounded delta. The yellow line in Figure 5(a) represents a prediction of the future shoreline of the lobate Wulan Delta.

\subsection{Landuses Changes on Wulan Delta}

The morphodynamic Wulan Delta triggers land use changes, with a prominent change experienced by fishponds, settlements, and mangroves. Wulan River has been transporting sediments from Serang Watershed to its mouth gradually since 1892 [8]. The land use in the upper part of this watershed consists of agricultural land and built-up land that causes an increase in sediment discharge. In the past 10 years, floods have been occurring in Wulan Delta causing more materials deposited downstream. The mud material is used as fishponds developed by the local community. These ponds are built manually by arranging mud material into a rectangle shape as the embankment. Silvofishery system has been implemented in the area by planting mangroves on the embankment. The presence of mangroves on the embankment protects these ponds from sea currents and waves. The tidal current is utilized to replace the water in the ponds and to transport fishermen to the sea.

The in-depth interviews to community leaders, fishponds farmers, and fishermen conclude that nowadays river floods no longer occur in Wulan Delta. This is deemed the result of successful Serang Watershed management including the land use management and dam development, conducted by Watershed Management Authority (BPDAS) of Jratunseluna as parts of strategies in managing soil erosion in the upper part of watershed and in fulfilling the water demand in Serang Watershed. Due to the lack of significant amount of sediment supply, the area of fishponds is not extendible. In some locations, fishponds have experienced damages due to the eroding currents and sea waves (Figure 6(a)), for example, the damages of the fishponds in Menco, Berahan Wetan Village due to coastal erosion have reached an extent of 30 - 40 hectares since 2005. Some farmers have been taking a mitigating effort by applying fishnets as barriers around the ponds in order to prevent fish from being swept away by the current. Furthermore, this temporary effort needs a day-to-day monitoring in order to ensure that pests do not perforate the fishnets.

Damages on the fishponds result in economic losses since aquaculture is the leading economic sector in the coastal villages in Wulan Delta. These ponds are used to breed milkfish, shrimp, and crab. In dry season, some fishponds are used as salt ponds. Normally, fish farmers earn IDR 3-5 million per month, while tenant fish farmers earn IDR 1.5 million per month. Nevertheless, coastal erosion causes fishpond damage that drastically decreases the income of the local households.

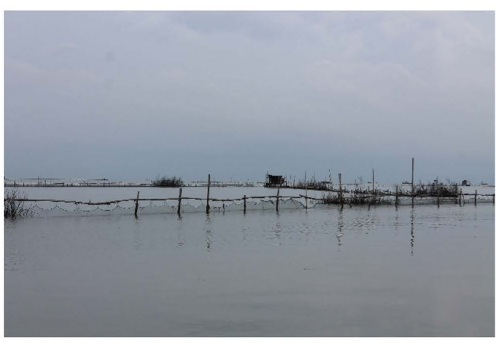

(a)

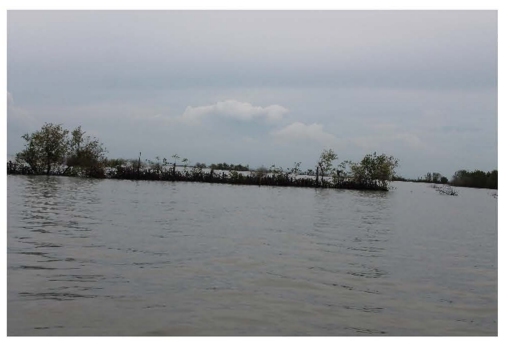

(b)

Figure 6. (a) The former fishponds are damaged due to erosive current and sea wave leaving the mangroves planted on their embankment; and (b) the damaged mangrove plants caused by the current and sea wave energy. 
Besides causing damages to fishponds, currents and sea waves also create damages to mangroves. Mangrove is an ecosystem found muddy coast with low wave energy, estuaries, lagoons, and deltas [26]. Giri et al. mentioned that mangrove is distributed in the inter-tidal region in the tropical and subtropical regions of the world between $30^{\circ} \mathrm{N}$ and $30^{\circ} \mathrm{S}$ latitude [27]. Mangrove ecosystem has a very important ecological function for the biological and physical balance in a delta. Mangrove indirectly support function to fishery by providing germplasm as the main food or the point of marine food chain [28]. They provide forest products as well as protect a coastal area from destructive sea waves so that damages occurred due to coastal erosion can be minimized. Mangrove ecosystem in Demak areas rapidly change mainly caused by instability of its coastal condition [29]. Not only do such damages affect the physical and biological condition, but also inflict economic losses to local community. Therefore, mangrove conversion into fishponds, aggravated by the continuously occurring coastal erosion, threats the sustainability of economic activities in the area.

The extent of mangroves decreased by 92.81 ha in 2000-2010 due to current and wave energy as well as landuse conversion into fishponds. The dominant mangrove found in this area is Rhizophora sp., whose stilt roots decrease the sea wave energy; therefore, this species survives in the outer side of delta. Other mangrove species growing in this area are Avicenniaalba, Sonneratia sp. and Bruguiera sp. Figure 6(b) shows the damages to mangroves due to current and seawave energy.

Settlement area in Berahan Wetan village increased 167 hectares in 2000-2010. Meanwhile, the settlement area has been developing in the last 20 years especially around the upper part of the delta, whose soil materials are more resistant. Menco, the closest settlement area to the coast (Figure 7), was initially used as temporary settlement and warehouse complex for fishermen and fish farmers. Due to increasing demand on space, the temporary settlement has been changing into permanent settlement since the 1990s. Most parts of the settlement are built linearly along the river levees due to the height advantage of this landform. Settlement in this area has a high vulnerability to both river floods and tidal inundation. The location of the settlement is adjacent to a large river channel located at low elevation and a flat topography. Exacerbated by sea level rise, this location is ex-

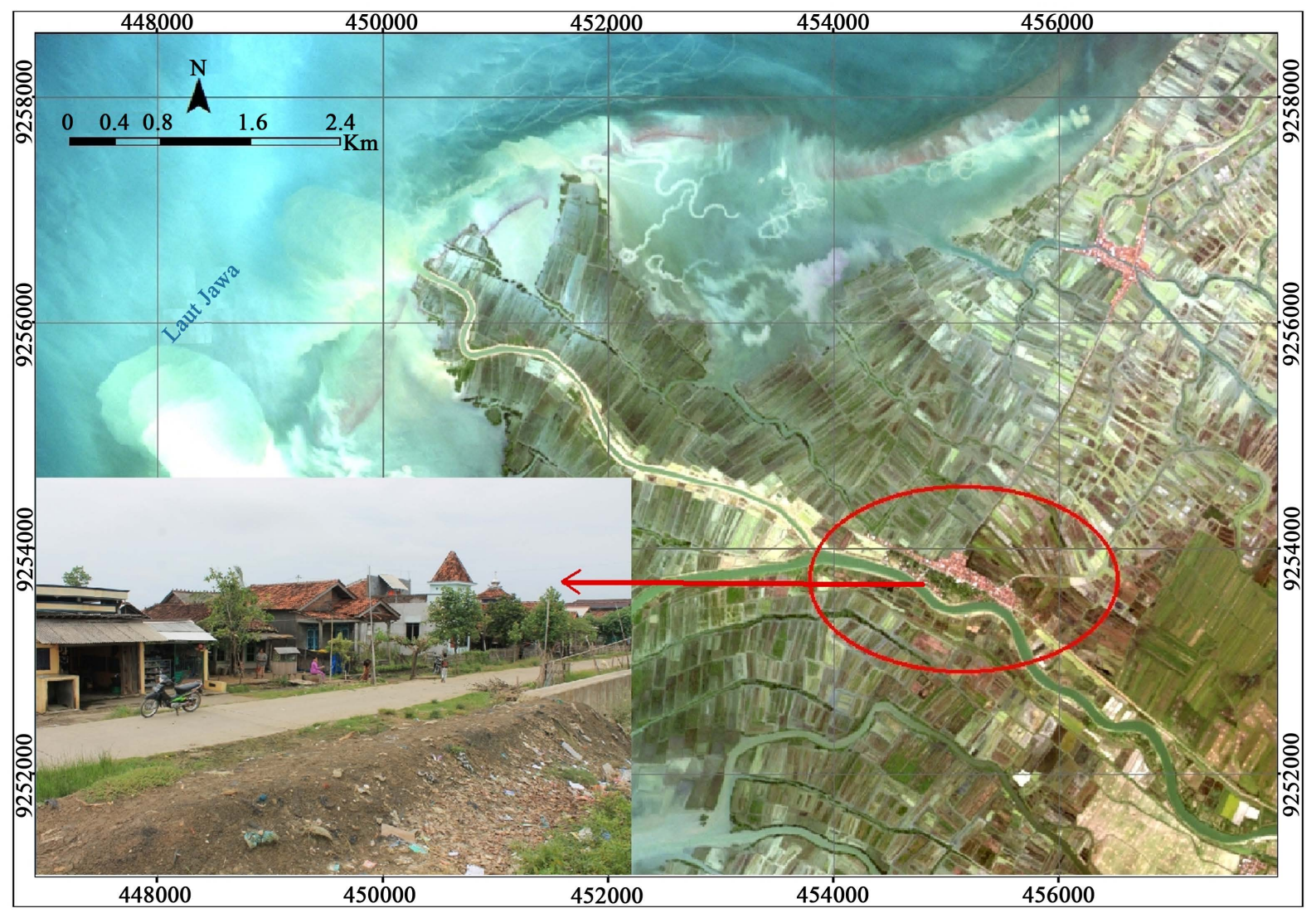

Figure 7. The settlement in Menco, Wulan Delta develops along the river. 
posed to river flood and tidal inundation hazard. The local community built concrete levees along the Wulan River. However, most settlement is still inundated during the high tides. In order to adapt with this hazard, the local community builds their houses with higher foundation in order to prevent the inundation from flowing into the house.

\subsection{Coastal Management Strategy}

The development of coastal villages cannot be separated from coastal management, especially on both problems and potentials of the area. Therefore, it is necessary to establish a development strategy to develop a sustainable coastal area based on ecology and community. The problems and potentials of a coastal area are inventoried based on their strengths, weaknesses, opportunities, and threats.

Beautiful scenery of Wulan Delta can be developed as a tourist area. Mangrove ecosystem and bird sanctuary increase the pulling factor of eco-based tourism. The potential of aquaculture practices need a more sustainable management in order to decrease the destructive impacts of coastal erosion on fishponds and mangroves, as well as to increase the economic condition in Wulan Delta. Moreover, the poor sanitation on the settlement area needs a further environmental management involving the government and the local community. In order to increase the adaptive capacity of the local community in Berahan Wetan, the central government and NGOs need to provide assistance to fish farmer and fishermen community and support in the form of ship loans. Unfortunately, parts of the community have not implemented the regulations issued by the government and suggested by NGOs. This area is exposed to the threats of river and tidal flood. Such exposure causes damages to the ponds and settlements and also inflicts economic and social losses.

SWOT analysis described above results in a formulation of several strategies in coastal management for the physical and social environment. Analysis of Internal Factor Analysis Summary and External Factor Analysis Summary (IFAS-EFAS) on the quadrant matrix of strategy shows that the coastal village of Berahan Wetan is suitably developed using an aggressive maintenance strategy, i.e. an active and aggressive management in solving the problems and increasing the potentials of the coastal village. The government has issued the zoning regulation for coastal area, however, the enforcement is low. The regional and local government should provide assistance to the community regarding the zoning regulations set by the government. Revision on the zoning regulations should include the participation of the community in order to obtain acceptable results for all parties. The quality of coastal ecosystem needs improvements in order to support the sustainability of fisheries and aquaculture practices. Silvofishery system is suitably applied on Wulan Delta, i.e. by planting mangroves around the fishponds; thus, the ponds become relatively safer from the coastal erosion. The outer side of the delta is a protected and a buffer zone. Therefore, an area with a width of $100 \mathrm{~m}$ from the shoreline is classified as coastal buffer zone based on Decree of the Ministry of Environment No. 201 in 2004. The protected area should be functioned as a green belt by planting mangrove as an ecological-based breakwater.

The development of coastal village as a tourist destination needs to consider public infrastructure. The procurement and revitalization of public facilities need water treatment, drainage channel management, and also waste management. Road network and public transport need an improvement considering the very limited infrastructures. Community empowerment through socialization on the importance of health and environmental sustainability is also important due its role as the key to improving the quality of human and environmental resources in coastal villages as well as the ability to develop their potential.

\section{Conclusion}

Wulan Delta had experienced morphological changes from straight then arcuate, into bird-foot (digitate) in 1931-2010. Nowadays, Wulan Delta has formed sand barrier in front of the delta which indicates the dominance of oceanographic processes rather than fluvial processes. This condition shows that Wulan Delta has a tendency to transform into a round delta (lobate) in the future. The progradation of Wulan Delta leads to land use changes in Wedung Sub-district. The settlement area had increased by 167 ha, while the fish ponds had increased by 1014 ha within a period of 2000-2010. The ponds are increased due to the conversion of mangroves into fishponds, as the main livelihood source of the local community. Besides experiencing land conversion, mangroves also experience damages due to coastal erosion. Coastal erosion occurs lately because there is a change in the pattern of sea currents and waves due to the obstruction created by the delta. Coastal erosion has also damaged 30 - 40 ha of fish ponds since 2005. Most settlements are built linearly along the river levees. Therefore, the set- 
tlement in this region has a high vulnerability to river floods and tidal inundation. The suitable development strategies for the coastal villages of Berahan Wetan is an aggressive maintenance strategy, with an improvement in public infrastructure, human resources quality, and the implementation of silvofishery system in the fish ponds management. The implementation of law enforcement on the zoning regulation as well as its socialization to the local community, become necessary in applying an integrated and sustainable coastal zone management.

\section{Acknowledgements}

This research is supported by Research Grant of International Corporation and Publication, Directorate General of Higher Education Indonesia 2015.

\section{References}

[1] Badan Informasi Geospasial (BIG) (2013) The Integrated Geospatial Information for Better Indonesia (IG yang terintegrasi untuk Indonesia yang lebih baik).

http://www.bakosurtanal.go.id/berita-surta/show/ig-yang-terintegrasi-untuk-indonesia-yang-lebih-baik

[2] CERC (1984) Shore Protection Manual. Vol. I, CERC Dept. of the Army, U.S. Army Corps of Engineers, Washington.

[3] Beatley, T., Brower, D. and Schwab, A.K. (2002) An Introduction to Coastal Zone Management. Island Press, Washington.

[4] Marfai, M.A. and King, L. (2008) Coastal Flood Management in Semarang, Indonesia. Environmental Geology, 55, 1507-1518. http://dx.doi.org/10.1007/s00254-007-1101-3

[5] Marfai, M.A. (2011) Impact of Coastal Inundation on Ecology and Agricultural Land Use Case Study in Central Java Indonesia. Quaestiones Geographicae, 30, 19-32. http://dx.doi.org/10.2478/v10117-011-0024-y

[6] Pallewatta, N. (2010) Coastal Zones and Climate Change. In: Michel, D. and Pandya, A., Eds., Coastal Zones and Climate Change, The Henry L. Stimson Center, Washington DC, 3-16.

[7] Bagli, S. and Soille, P. (2003) Morphological Automatic Extraction of Pan-European Coastline from Landsat ETM + Image. Proceeding ofThe 5th International Symposium on GIS and Computer Cartography for Coastal Management, Genova, 26 September 2003, 58-69.

[8] Sunarto (2004) Geomorphic Changes in Coastal Area Surround Muria Volcano, Perubahan Geomorfik di Kawasan Pesisir Sekitar Gunungapi Muria. PhD Thesis, Universitas Gadjah Mada, Yogyakarta.

[9] Hutabarat, S. and Stewart, M.E. (1985) Introduction of Oceanography, Pengantar Oseanografi. Universitas Indonesia, Jakarta.

[10] Triatmojo, B. (1996) Port, Pelabuhan. Beta Offset, Yogyakarta.

[11] Moon, I. (2005) Impact of a Coupled Ocean Wave-Tide-Circulation System on Coastal Modeling. Ocean Modeling Elsevier, 8, 203-236. http://dx.doi.org/10.1016/j.ocemod.2004.02.001

[12] McLean, R., et al. (2001) Coastal Zone and Marine Ecosystems. In: McCarthy, J.J., Canziani, O.F., Leary, N.A., Dokken, D.J. and White, K.S., Eds., Climate Change 2001: Impacts, Adaptation and Vulnerability, Cambridge University Press, Cambridge, 345-379.

[13] Dongeren, A., van Ormondt, M., Sembiring, L., Sasso, R., Austin, M., Briere, C., Swinkels, C., Roelvink, D. and Vries, J.T. (2013) Rip Current Prediction through Model-Data Assimilation on Two Distinct Beaches. Coastal Dynamics, 1775-1785.

[14] Ataei, A. and Lashteh, H. (2014) Classification of Equilibrium Beach Profile in the Caspian Sea. International Geoinformatics Research ad Development Journal, 6, 8-18.

[15] Malvarez, G.C., Cooper, J.A.G. and Jackson, D.W.T. (2001) Relationship between Wave-Induced Currents and Sediment Grain Size on a Sandy Tidal Flat. Sedimentary Research, 71, 705-712. http://dx.doi.org/10.1306/2DC40961-0E47-11D7-8643000102C1865D

[16] Arnott, R.D. (2010) An Introduction to Coastal Processes and Geomorphology. Cambridge University Press, Cambridge.

[17] Bird, E.C.F. and Ongkosongo, O.S.R. (1980) Environmental Changes on the Coasts of Indonesia. The United Nations University, United Nations University Press, Tokyo.

[18] Summerfield, M.A. (1991) Global Geomorphology: An Introduction to the Study of Landform. John Wiley and Sons Inc., New York.

[19] Ongkosongo, O.S.R. (2010) Estuary, River Mouth, and Delta; Estuari, Muara Sungai dan Delta. Lembaga Ilmu Pengetahuan Indonesia, Bandung. 
[20] Peng, J., Chen, S. and Dong, P. (2010) Temporal Variation of Sediment Load in The Yellow River Basin, China, and Its Impacts on the Lower Reaches and the River Delta. Chinese Geographical Science, 22, 507-521. http://dx.doi.org/10.1016/j.catena.2010.08.006

[21] Chen, X.Q. (1998) Changjiang (Yangtse) River Delta. Coastal Research, 14, 838-858.

[22] Arisanty, D., Sartohadi, J., Marfai, M.A. and Hadmoko, D.S. (2012) The Long-Term Morphodynamic of Barito Delta, Southern Kalimantan, Indonesia. Environmental Science and Engineering, B1, 1196-1202.

[23] Susilawati and Jaya, I.N.S. (2003) Evaluation of Residual Rods Because of Harvesting Use Landsat ETM+ in HPH PT Sri Buana Dumai Provinsi Riau. Management Hutan Tropika, 9, 1-16. (In Bahasa)

[24] Revianda, P. (2008) Study of Wulan River Capacity by Using HEC-RAS 4.0 Software. Bachelor's Thesis, Universitas Katolik Soegipranata Semarang, Semarang.

[25] Kloosterman, F.H. (1989) Groundwater Flow Systems in the Northern Coastal Lowlands of West- and Central Java, Indonesia. PhD Dissertation, Vrije University, Amsterdam.

[26] Hogarth, P. (2007) The Biology of Mangroves and Sea Grasses. Oxford University Press, New York. http://dx.doi.org/10.1093/acprof:oso/9780198568704.001.0001

[27] Giri, C., Ochieng, E., Tieszen, L.L., et al. (2011) Status and Distribution of Mangrove Forest of the World Using Earth Observation Satellite Data. Global Ecology and Biogeography, 20, 154-159. http://dx.doi.org/10.1111/j.1466-8238.2010.00584.x

[28] Walter, B.B., Rönnbäck, P., Kovacs, J.M., et al. (2008) Ethnobiology, Socio-Economics and Management of Mangrove Forest: A Review. Aquatic Botany, 89, 220-236. http://dx.doi.org/10.1016/j.aquabot.2008.02.009

[29] Hastuti, E., Anggoro, S. and Pribadi, R. (2012) The Effect of Environmental Factors on the Dynamic Growth Pattern of Mangrove Avicennia marina. Coastal Development, 16, 57-61. 